Тищенко В. Ф., д.е.н., доцент

Шаповалова А. О., аспірант

Харківський начіональний економічний університет імені Семена Кузнеия м. Харків, Україна

DOI: https://doi.org/10.30525/978-9934-26-036-0-13

\title{
НОРМАТИВНО-ПРАВОВЕ РЕГУЛЮВАННЯ ІННОВАЦІЙНОЇ ДІЯЛЬНОСТІ МСП В УКРАЇНІ
}

Для сталого розвитку держави необхідно створити сприятливі умови для формування та функціонування інноваційних підприємств, розвитку національної інноваційної системи, залучення інвестиційних коштів у сферу інновацій. Структурні елементи національної інноваційної системи та правове регулювання їх функціонування в Україні не інтегровані в єдину структуру, тому результати діяльності даних елементів не зв'язані між собою, що перешкоджає збільшенню ефективності національного виробництва товарів (послуг) і посилення їх конкурентоспроможності за рахунок широкомасштабного впровадження результатів наукових досліджень і науково-технічних (експериментальних) розробок.

В нормативно-правовому забезпеченні немає документу, який спрямований на розвиток інноваційної діяльності в усіх сферах 
економіки, який забезпечуватиме системність заходів та сприятиме розвитку як технологічних, так і соціальних інновацій, створення високих технологій та їх впровадження. На регіональному, національному та наднаціональному рівнях забезпечення інноваційності економічного розвитку відбувається завдяки концепції кластерного розвитку, спрямоване на активне залучення МСП.

В даний час українське законодавчо-нормативне забезпечення підтримки МСП складається 3 двох рівнів (рис. 1).

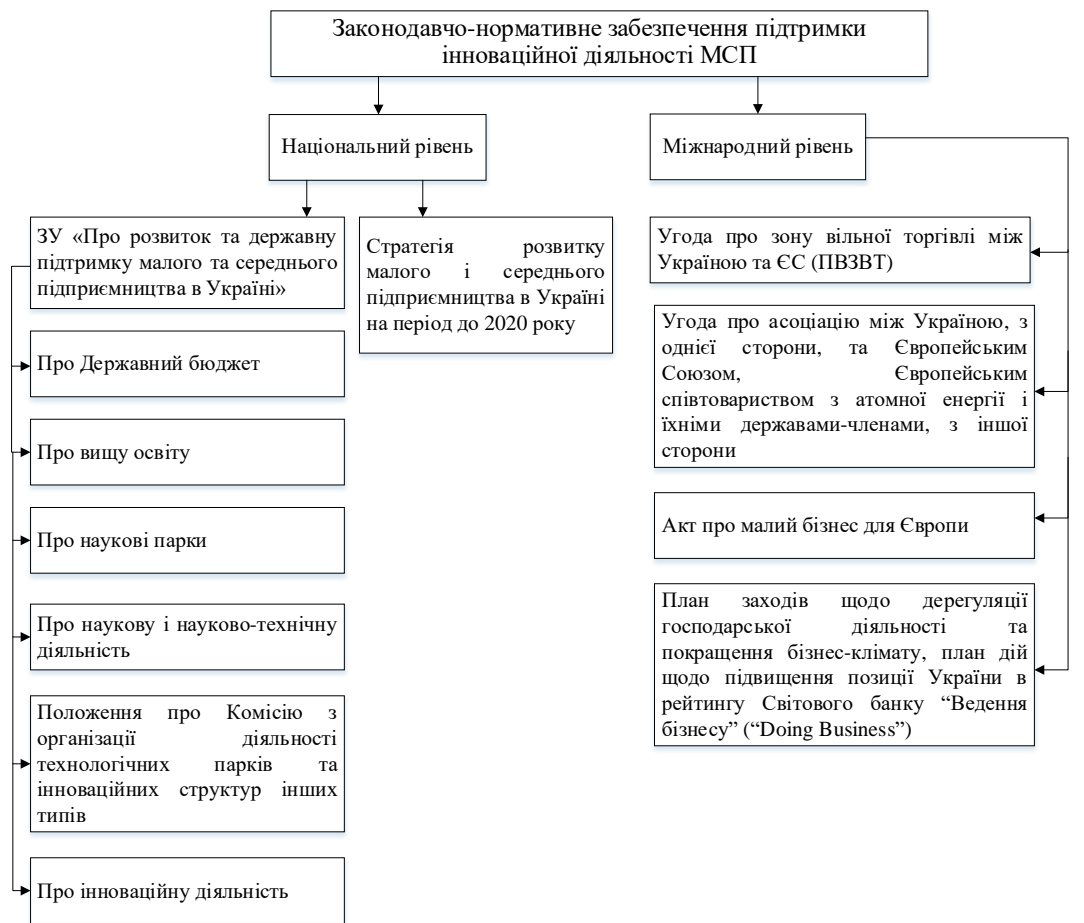

\section{Рис. 1. Законодавчо-нормативне забезпечення підтримки інноваційної діяльності МСП}

Урядом розглянуто ряд перспективних законопроектів, зокрема, проекти Законів України: «Про підтримку та розвиток інноваційної діяльності», «Про внесення змін до Податкового кодексу України щодо встановлення спеціального податкового 
режиму» та інших, які частково передбачали різні засоби i пропозиції покращення інвестиційного клімату, створення сприятливіших умов розвитку МСП і стартапів в Україні та іiі містах, проте їх було відхилено.

Позитивним $\epsilon$ прийняття Розпоряджень КМУ «Про затвердження плану заходів з реалізації Стратегії розвитку малого $\mathrm{i}$ середнього підприємництва в Україні на період до 2020 року» [1], «Про схвалення Стратегії розвитку сфери інноваційної діяльності на період до 2030 року» [2], «Про схвалення Національної екпортної стратегії» [3], тощо, які дозволять збільшити частки підприємств, які займаються винахідництвом, прикладними дослідженнями та науково-технічними розробками, зокрема, малих, насамперед - за межами державного сектору та збільшити надходжень від продажу та використання (насамперед, експорту) об’єктів інтелектуальної власності, наукоємної продукції.

Протягом 2013-2018 років в Україні схвалено майже 40 стратегічних документів галузевого рівня, що стосуються розвитку інновацій в тій чи іншій сфері. Їх аналіз свідчить, що всі документи містять заходи щодо підтримки інноваційної діяльності у кожній окремій сфері. Проте слід відмітити, що незважаючи на спроби активізації інноваційної діяльності, їх не було реалізовано у повному обсязі. Пріоритетні напрями інноваційної діяльності загальнодержавного рівня на 2012-2021 роки визначено постановами КМУ № 294 від 12 березня 2012 р. [4], № 397 від 17 травня 2012 р. [5] та постановою КМУ № 1056 від 28 грудня 2016 р. [6]. Інформація щодо державно-цільових програм на сайті МОНу не оновлювалась із 2012 p.

Загалом, в Україні є позитивні тенденції щодо політики у сфері інновацій. Нормативно-правове забезпечення інноваційної діяльності МСП знаходиться в процесі становлення, поступово удосконалюється і вже найближчим часом зможе стати основою для активізації і підвищення ефективності цих підприємств. Для розвитку підприємництва, крім загальнонаціонального законодавства, важливе значення мають регіональні програми та 
стратегії підтримки МСП, інші документи регіонального та місцевого значення.

\section{Література:}

1. Деякі питання реалізації Стратегії розвитку малого і середнього підприємництва в Україні на період до 2020 року: Розпорядження КМУ від 10 травня 2018 р. № 292-p. URL: https://zakon.rada.gov.ua/laws/show/292-2018$\% \mathrm{D} 1 \% 80 \#$ Text.

2. Про схвалення Стратегії розвитку сфери інноваційної діяльності на період до 2030 року : Розпорядження КМУ від 10 липня 2019 р. № 526-p. URL: https://zakon.rada.gov.ua/laws/show/526-2019-\%D1\%80\#Text.

3. Про схвалення Експортної стратегії України («дорожньої карти» стратегічного розвитку торгівлі) на 2017-2021 роки : Розпорядження КМУ від 27 грудня 2017 p. № 1017-p. URL: https://zakon.rada.gov.ua/laws/show/1017-2017$\%$ D1\%80\#Text.

4. Про затвердження критеріїв оцінки допустимості державної допомоги суб'єктам господарювання на проведення наукових досліджень, технічний розвиток та інноваційну діяльність: Постанова КМУ від 7 лютого 2018 р. № 118. URL: https://zakon.rada.gov.ua/laws/show/118-2018-\%D0\%BF\#Text.

5. Деякі питання визначення середньострокових пріоритетних напрямів інноваційної діяльності загальнодержавного рівня на 2012-2016 роки: Постанова КМУ від 12 березня 2012 р. № 294. URL: https://zakon.rada.gov.ua/laws/show/2942012-\%D0\%BF\#Text.

6. Деякі питання визначення середньострокових пріоритетних напрямів інноваційної діяльності загальнодержавного рівня на 2017-2021: Постанова КМУ від 28 грудня 2016 p. № 1056. URL: https://zakon.rada.gov.ua/laws/ show/1056-2016-\%D0\%BF\#Text. 